Набочук Олександр

кандидат психологічних наук, Радник голови Рівненської обласної ради https://orcid.org/0000-0002-1448-7687

DOI https://doi.org/10.35619/praprv.v1i16.216

\title{
АНАЛІЗ ПРОБЛЕМИ ПСИХОЛОГІЧНИХ ЧИННИКІВ, ЩО ВИЗНАЧАЮТЬ ЗДАТНІСТЬ КЕРІВНИКА ДО ПРОФЕСІЙНОЇ ТВОРЧОСТі
}

\begin{abstract}
Анотація. В статті досліджено проблему професійної творчості керівника. Зазначено, щу в більшості теоретичних визначень сутності творчості досить експресивно, презентабельно та експлічитно виявляється орієнтація на прочесуальну,
\end{abstract} продуктивну та особистісну сторони творчості.

Описано проведене нами емпіричне дослідження з метою встановлення рівню сформованості креативної мотивації та креативної спрямованості особистості керівників педагогічних освітніх установ, а також їх соціального інтелекту та тривожності як індивідуальної характеристики, щуо дасть нам можливість сформулювати психологічні чинники, що визначатимуть здатність керівника до професійної творчості. Встановлено зв'язок між соціальним інтелектом та тривожністю керівників освітніх установ. При цььому значущі негативні кореляційні зв'язки були встановлені між соціальним інтелектом та ситуативною тривожністю, а також між соціальним інтелектом та тривожністю, пов'язаною з діяльністю і самооцінкою.

Теоретичний аналіз проблеми професійної творчості керівника та проведене емпіричне дослідження дозволило нам сформулювати такі психологічні чинники, що визначають здатність керівника до професійної творчості:

- професійною підготовкою керівників у вищих закладах освіти, зумовленою становленням особистісно та професійно значущого досвіду, сформованістю творчих здібностей та здатностей особистості; при изьому иі творчі здібності та здатності будуть спрямовані на досягнення ціннісних, аксіологічно значущих результатів не лише у професійній парадигмі, а й у всіх сферах життєдіяльності індивіда;

- високий рівень розвитку соціального інтелекту керівника, щзо передбачає здійснення особистістю творчих дій на рівні метаінтелектуальної діяльності, саме на якому і відбувається істинно творча діяльність, щуо призводить до експлікачії творчих здобутків особистості. Саме завдяки даному, четвертому рівневі інтелекту людина здатна встановлювати взаємодію не лише із різними об'єктами та іншими людьми, а й зі світом в иілому, розширюючи тим самим межі свого інтелекту і розпочинаючи діалог із творчим початком світу;

- низький рівень тривожності особистості, щзо, в свою чергу, сприятиме формуванню аксіологічного творчого потенціалу особистості як фрейму, щцо є запобіжним фактором иіннісної дезорієнтації керівника, нівелювання ним творчих, життєздатних змін ціннісних орієнтирів, щуо, в свою чергу, може призвести до морального нігілізму, професійного вигорання або й до стану професійної деградації особистості.

Ключові слова: професійна творчість, креативна мотивачія, креативна спрямованість, соціальний інтелект, ситуативна тривожність, аксіологічний творчий потенціал особистості.

Постановка проблеми. Генезис ідей психології творчості у вітчизняній психології, теоретико-методологічні особливості загального підходу до грунтовних психологічних досліджень, динаміка перетворень та тенденції стратегічного розвитку розкрито у багатьох наукових працях (Завгородня, 2007; Лейтес, 1992; Матюшкин, 1993).

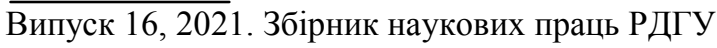


У науковій літературі (Post, 1994) зазначено, що емоційні якості виявляються на практиці головним чином через характер людини. Вони мають як генетичну, так i виховну основу. Вивченням взаємозв'язку емоційних якостей особистості із здатністю до професійної творчості займалися багато вчених, що призвело до появи досить-таки грунтовного переліку цих якостей. Проте, в наукових дослідженнях вони так і не отримали свого підтвердження практикою свого зв'язку із здатністю до професійної творчості (Post, 1994).

Аналіз останніх досліджень і публікацій. Однією з досить-таки із оригінальних вітчизняних теорій творчості, предметом дослідження якої $\epsilon$ творчий продукт, $\epsilon$ теорія Виготського. У праці «Психологія мистецтва» загальну стратегію дослідження вчений формулює таким чином: творчість зумовлюється формою художнього твору завдяки функціональному аналізові його елементів, що фасилітує відтворення естетичної реакції особистості і призводить до встановлення, унормування в цілісну систему її загальних законів (Виготський, 1997). Таким чином, в теорії.Виготського базовою парадигмою дослідження був художній твір. Спираючись на досягнення формальної наукової школи, в якості одиниць творчого аналізу Виготський диференціює «матеріал» i «форму». Аналізуючи взаємовідносини форми і матеріалу, вчений приходить до висновку, що основою художньої творчості $€$ вивчення суперечностей між матеріалом і формою. В такому розумінні художній текст будується таким чином, що його матеріал постає зорієнтованим на один емоційний полюс, тоді як форма - на протилежний. Цей когнітивний дисонанс форми і матеріалу, його розвиток в парадигмі зіштовхнення протилежних полюсів (катарсис) створює динамічну структуру художнього тексту, яка, в свою чергу, фаси літує особистість до творчості. Таким чином, у Виготського психологія творчості спирається, перш за все, на дослідження емоцій, почуттів, афектів, переживань. Вчений формулює домінувальні закони створення загального творчого емоційного знаку і опанування особистістю творчої емоційної реальності уяви.

Сутність закону творчого емоційного знаку полягає в тому, що «будь-яке почуття, будь-яка емоція прагне втілитися, «увійти» до парадигми відомих образів, які відповідають творчому почуттю індивіда. При цьому емоція має своєрідну властивість підбирати дотично до творчого акту враження або образи, які $\epsilon$ досить-таки співзвучними тому настрою, який має місце в дану хвилину, коли створюється творчий продукт. Враження і образи, які окреслені загальними емоційними характеристиками, мають тенденцію об'єднуватися між собою, не дивлячись на те, що як такого базового, домінувального зв’язку ані за подібністю, ані за суміжністю не існує.

Закон творчої емоційної реальності уяви виявляється в тому, що будь-яка побудова фантазії зазвичай впливає на наші почуття, і якщо ця побудова і не відповідає сама собою оточуючій нас дійсності, то все ж таки викликане нею почуття є дійсним, реально пережитим, таким, що захоплює людину в цілому. Таким чином, Виготський 3 усією очевидністю актуалізував проблему взаємозв'язків емоцій та творчості. Разом 3 тим, внесок Виготського в розробку теорії психології творчості цими висновками не обмежується. Теорія вченого щодо розвитку вищих психічних функцій є своєрідним «перетворенням» «натуральних» функцій в «культурні». Теорія «психологічних систем», таким чином, сприяє переходу цілісних креативних новоутворень у вигляді різноманітних творчих продуктів міжфункціональних зв'язків, які, безперечно, мають принципове значення для психології творчості. У контексті нашого дослідження ці ідеї Виготського $\epsilon$ надзвичайно актуальними, через обгрунтування гіпотези щодо багаторівневої структури креативності як «системи міжфункціональних зв'язків».

У вітчизняній психології цілісну концепцію творчості як психічного процесу запропонував Пономарьов - автор абстрактно-аналітичної теорії творчості, ключовими категоріями якої є: визнання інтелектуальної активності, сензитивності, біполярності творчого процесу та створення структурно-рівневої моделі, в основу якої покладені психологічні механізми творчості (Пономарьов, 1991). Творчість в концепції Пономарьова розглядається як атрибут креативної матерії, як взаємодія, яка фасилітує 
особистісний розвиток. Сутність креативності як психічного новоутворення зводиться, передусім, до інтелектуальної активності і чутливості (сензитивності) як своєрідних побічних продуктів професійної діяльності. Творча людина по-особливому сприймає на розуміє побічні результати своєї професійної діяльності, які і є творінням нового, тоді як нетворча людина бачить творчі результати лише після досягнення індивідом цілей, які, на думку індивіда, є доцільними, що змушує особистість уникати новизни як такої.

Отже, метою нашої статті $\epsilon$ проведення емпіричного дослідження 3 метою встановлення рівню сформованості креативної мотивації та креативної спрямованості особистості керівників педагогічних освітніх установ, а також їх соціального інтелекту та тривожності як індивідуальної характеристики, що дасть нам можливість сформулювати психологічні чинники, що визначатимуть здатність керівника до професійної творчості.

Виклад основного матеріалу дослідження. Взагалі дослідження феномену творчості мають глибокі філософські традиції, актуальні і наш час (Бердяєв, 2008). Зокрема, Бердяєв розглядає проблему творчості в філософському, релігійному та психологічному контекстах. Творчість, на його думку, є шляхом до Бога, продовженням світобудови, своєрідною духовною еволюцією, таким окремим видом діяльності, який робить людину людиною. Бердяєв акцентує увагу не на результативній стороні творчості, а на кульмінації творчого процесу - на стані творчого осяяння, озаріння, екстазу, етапові, який саме фаси літує створення творчого продукту. Творчість полягає не стільки у оформленні в парадигмі гармонійного, завершеного творчого продукту, скільки в розкритті нескінченного; творчість - це своєрідний політ у нескінченність (Бердяев, 2016). Філософи нерідко констатують увагу на парадоксі парадокс подвійності творчості. При цьому творчий акт розглядається як своєрідний прорив у нескінченність, при цьому продукти творчості є досить-таки скінченними, обмеженими в теоретичному та практичному планах, 3 огляду на їх складні характеристики і системи, які ці характеристики створюють. Також вчені (Батищев, 1998) нерідко наголошують, що творчість ніби «спрямована» до культури, до Землі, локалізована в часових та просторових межах та контекстах.

Філософія творчості у Бердяєва безпосередньо пов'язана з філософією свободи. При цьому в працях вченого зазначається, що творчий акт не може цілковито експлікуватися за допомогою матеріалу (тобто, - засобів, технологій), які вже існують у світі, в ньому і полягає новизна продукту, який створюється. Новизна сама по собі і $є$ елементом свободи. В творчості і полягає «таємниця» творчості. В цьому сенсі творчість є ніби творчим актом, породженим «з нічого». Вона не визначається та не обгрунтовується ніякими факторами ззовні. Поза цим сенсом творчість постає лише перерозподілом елементів світу, при цьому виникнення новизни як такої нерідко здається для дослідника примарним процесом. Творчі здібності, на думку Бердяєва (2019), даються людині Богом, але те, як вона скористається цими здібностями, залежить, передусім, від самої людини. У роботах цього автора виокремлюється також психотерапевтична та розвивальна функції творчості. Творчість, на його думку, є одним із шляхів зцілення «хворобливої сутності» людини. У творчості долається роздвоєність $\mathrm{i}$, в той же час, особистість «загартовується» в цьому творчому самовизначенні, само реалізується, розвивається, тобто, відбувається становлення особистості. У роботах інших авторів творчість визначається як протилежна характеристика егоцентризму, забуття про себе, прагнення до того, що є вищим за особистість (Богоявленська, 1983). Поглинання особистістю самої себе нерідко пригнічує індивіда, передбачає його ніби «вихід» із себе, тим самим - звільняє. Творчість $\epsilon$ ніби спрямованістю особистості на перетворення світу, «піднесення» людини «до нового неба і нової землі».

У філософсько-лінгвістичній концепції Парсонса і його послідовників сутність творчості пов'язувалась із законами, які здійснюють управління Всесвітом. Таким чином, творчість тлумачилась як особливий вид компресії думок (Парсонс, 1985). У працях Post представлено своєрідну позиція розуміння творчості з точки зору піi рефлексологічної концепції. Вчений визначає творчість як творення чогось нового в 
ситуаціях, коли проблема, що оцінюється як своєрідний «подразник», викликає виникнення певної домінанти, навколо якої ніби концентрується необхідний для оцінювання набутий індивідом особистісний та професійно значущий досвід (Рost, 1994).

У більшості теоретичних визначень сутності творчості досить експресивно, презентабельно та експліцитно виявляється орієнтація на процесуальну, продуктивну та особистісну сторони творчості. Так, Рубінштейн (1989) визначає творчість як своєрідну творчу діяльність, як знаходження дещо нового, оригінального, яке входить не тільки до парадигми історії особистісного розвитку самого творця, але й до історії розвитку науки, мистецтва, суспільства і т.д. На думку Amabile (1983), творчість має на увазі творення нового, під чим розуміється процес перетворення у свідомості поведінки суб'єкта, також як і породжені ним, й разом з тим відчужені від нього індивідуальні продукти. Amabile, застосовуючи системно-структурний підхід до дослідження творчості, дійшов до висновку про те, що психологія не здатна «проникнути» до таємниць творчості, використовуючи тільки свої індивідуально окреслені засоби, безвідносно до історії культури як такої. Творчість за своєю природою є системно організованим об'єктом, адекватно збагненним лише в парадигмі міждисциплінарного дослідження. Така позиція, на нашу думку, $\epsilon$ надзвичайно актуальною i може розглядатися як одна із методологічних основ сучасних як теоретичних, так і практико зорієнтованих досліджень творчості.

Опишемо результати проведеного нами емпіричного дослідження. На початку проведення експерименту нас цікавило, передусім, вплив психологічних та емоційних якостей керівника на його здатність до творчості. Також завданням нашого дослідження $\epsilon$ вивчення розумових або інтелектуальних якостей керівників освітніх установ та їхнього зв'язку 3 професійною творчістю особистості. Таке вивчення також здійснювалось багатьма вченими (Лейтес, 1992; Пономарьов, 1991), проте в загальному отримані ними результати співпадають у тому, що низький рівень інтелекту гальмує здатність людини до творчості, проте високий рівень не обов'язково свідчить про те, що дана людина є творчою особистістю. Проте ці дослідження не стосувалися працівників педагогічної сфери діяльності, а, тим паче, керівників закладів освіти. I, нарешті, особистісні та ділові якості керівників приймають в більшій мірі характер набутих i розвинених у керівників навичок і вмінь у виконанні ними своїх функцій. Доведено, що значущість цих якостей має позитивну кореляцію із виконанням керівником своїх безпосередніх обов'язків та функцій, проте ще не було доведено, що ці якості $\epsilon$ визначальними для професійної творчості.

Обгрунтуємо, чому в емпіричній частині дослідження ми вивчали рівень сформованості соціального інтелекту респондентів. Ми виходили із концепції Івашкевича, а саме 3 того, що кожен вид інтелекту вміщує певні окремі здібності особистості до виконання конкретного виду діяльності. При цьому, зокрема, Івашкевич «лінгвістичний інтелект» називає саме «інтелектом», адже це - комплексне інтегральне утворення, яке включає окремі здібності до виконання лінгвістичних дій, а якщо ми говоримо про фахівця педагогічної сфери діяльності - то й компетентності, що, в свою чергу, входитимуть до структури професійної компетентності особистості (Івашкевич, 2018, с. 86). Івашкевич пропонує рівневу теорію інтелекту. Перший рівень вчений вважає рівнем функціонування когніцій, до яких відносяться домінувальні психічні процеси (відчуття, сприймання, пам'ять, увага, які, в свою чергу, «контролюють» плин пізнавальної діяльності), а також мислення та уява, мова і мовлення. Другий рівень інтелекту - рівень метакогніцій (метакогнітивні інтегратори, «вторинні» психічні процеси), які раптово виникають й раптово зникають, серед яких основними автор вважає інтелектуальну ініціацію (самостійне формулювання задачі), рефлексію, децентрацію, інтелектуальні стратегії та уміння (здатності та компетентності), а також метакогнітивний моніторинг, інтуїція, інтелектуальні атитюди (цінності, смисли). Перший та другий рівні інтелекту, на думку Івашкевича, цілковито усвідомлюються особистістю, яка здійснює інтелектуальну діяльність. Третій рівень 
інтелекту ампліфікує характеристики як першого, так i другого рівнів, при цьому інтелектуальна діяльність здійснюється переважно на неусвідомлюваному рівні, рівні, який наближує особистість до використання автоматизованих навичок та вмінь. Наступний, четвертий рівень, - рівень метаінтелектуальної діяльності, на якому відбувається творча діяльність, що призводить до експлікації творчих здобутків особистості. Івашкевич вважає, що саме завдяки даному, четвертому рівневі інтелекту людина здатна встановлювати взаємодію не лише із різними об'єктами та іншими людьми, а й зі світом в цілому, розширюючи тим самим межі свого інтелекту і розпочинаючи діалог із творчим початком світу (Івашкевич, 2018, с. 84-85).

Перераховані нами особливості і визначили процедуру проведення емпіричного дослідження на даному етапі експерименту. Дослідження проходило в три етапи, протягом 2018-2021 pр. Перший етап - підготовчий, який включав підбір методик, створення та стандартизацію авторського опитувальника, спрямованого на вимірювання різних видів тривожності, складання експертної оцінки. Другий етап - власне дослідницький, був присвячений збору психодіагностичних даних.

До вибірки респондентів увійшли керівники освітніх установ:

- $\quad$ група F1 - 24 директори закладів дошкільної освіти (дошкільні установи м. Рівного та Рівненського району, міст. Києва, Одеси, Кам'янець-Подільського);

група F2 - 48 директорів закладів загальної середньої освіти (м. Рівного та Рівненського району, м. Києва, м. Одеси, м. Кам'янець-Подільського);

- $\quad$ група F3 - 28 ректорів та проректорів закладів вищої освіти (Рівненський державний гуманітарний університет, Міжнародний економіко-гуманітарний університет, Кам'янець-Подільський національний університет імені Івана Огієнка, Переяслав-Хмельницький державний педагогічний університет імені Григорія Сковороди, Луцький національний технічний університет, Волинський національний університет імені Лесі Українки). Дана вибірка завдяки своїй чисельності $\epsilon$ репрезентативною. Групи були сформовані за випадковим методом. Групу F1 становили всі жінки, тоді як до групи F2 входили 18 чоловіків і 30 жінок, до групи F3 - 18 чоловіків і 10 жінок.

Третій етап - статистичний аналіз отриманих результатів. Отримані дані були оброблені за допомогою комп'ютерного пакету статистичних програм «Statistica»: версія 12.5.192.7, призначеної для роботи з таблицями числових даних. Був використаний критерій $\varphi^{*}-$ кутове перетворення Фішера, призначений для зіставлення двох вибірок за частотою появи того ефекту, що цікавить дослідника.

Програма дослідження включала наступні методики: «16-ти факторний опитувальник» (Тест Кеттелла (2021); Фрайбургський багатофакторний особистісний опитувальник (Тест FPI, 2021); тест «Соціальний інтелект» (авт. Гілфорд, О’Саллівен, в адапт. Михайлової, 2021). Методика «Соціальний інтелект» спрямована на вимірювання загального рівня соціального інтелекту та загальних здібностей до розуміння поведінки людини. Вона включає чотири субтести: перший - спрямований на виявлення здатності передбачати наслідки поведінки; другий визначає здатність відображати невербальну експресію поведінки; третій субтест виявляє здатність адекватно відображати вербальну експресію поведінки; четвертий - визначає здатність до розуміння логіки розвитку складних ситуацій, ситуацій міжособистісної взаємодії.

Загальний рівень розвитку соціального інтелекту визначається на основі композитної оцінки.

1. Шкала реактивної та особистісної тривожності Спілбергера-Ханіна (2013). Ця методика дозволяє визначити рівень тривожності особистості як своєрідної індивідуальної чутливості до стресу і як рису особистості, яка характеризується схильністю респондента в тій чи іншій мірі відчувати ситуації занепокоєння, побоювання тощо.

2. Методика, спрямована на виявлення тривожності, пов'язаної з управлінською діяльністю, із взаємостосунками i самооцінкою особистості, розроблена та 
стандартизована нами для цілей і завдань нашого емпіричного дослідження («Методика вимірювання тривожності в професійній діяльності керівника») (Михальчук, Набочук \& Івашкевич, 2021).

5. Тест «Спрямованість особистості» (Смекало та Кучер, 1977). Дана методика використовується для визначення креативної спрямованості фахівця. Текст методики містить 27 тверджень; пропонується по три варіанти відповіді у кожному завданні. Респондентам було необхідно у відповідь на кожне твердження обрати один із запропонованих варіантів відповіді.

За допомогою цієї методики виявляються такі види спрямованості: спрямованість на себе, спрямованість на справу (професію), спрямованість на розв'язання завдання або задачі. Ми вважаємо, що креативну спрямованість можна діагностувати як спрямованість на певну конкретну справу, тому що експлікація креативних рис особистості відбувається саме в процесі професійної діяльності. Далі відповідно до ключа визначався рівень креативної спрямованості фахівця.

До групи експертів увійшли 9 докторів психологічних наук Рівненського державного гуманітарного університету та 8 докторів психологічних наук ПереяславХмельницького державного педагогічного університету імені Григорія Сковороди, 2 iз яких у свій час працювали на посадах проректора, 2 працюють на посадах проректора в даний час, 7 докторів наук є діючими завідувачами кафедр та деканами факультету. Тобто, експертами виступили керівники, які знають особливості діяльності керівника, ознайомлені із особливостями творчого характеру управлінської діяльності тощо.

Дослідження проводилося кожним експертом окремо в ході індивідуальних зустрічей. Експертам пояснювалося, що зазначені в бланку експертної оцінки якості мають бути оцінені ними стосовно конкретної людини за п'ятибальною шкалою. Після того як, експерти виставляли оцінки, нами підраховувалась сума балів за кожною 3 дев'яти характеристик. Загальний середній бал підраховувався за такою схемою: спочатку обчислювалася сума балів, виставлених кожним експертом за всіма дев'ятьма показниками, потім визначався середній бал за результатами роботи кожного експерта; згодом підраховувалась сума балів, виставлених усіма експертами за кожному з дев'яти показників та середній бал за результатами роботи всіх експертів. На останньому етапі дослідження обчислювалась загальна сума балів за результатами роботи всіх експертів та загальний середній бал експертної оцінки. Загальний середній бал експертної оцінки дозволяв нам зробити висновок щодо успішності або неуспішності керівника у професійній діяльності.

Показником успішності були високі оцінки експертів за характеристиками індивідуальних рис суб'єкта, які відповідають вимогам, що ставляться до людини, яка обрала педагогічну професію. Такими характеристик для керівників педагогічної сфери діяльності були: педагогічна спостережливість, організаторські здібності, які забезпечують включення здобувачів освіти до різних видів діяльності, вміння створювати проблемні ситуації, стимулювати пізнавальну самостійність, самооцінка результатів своєї діяльності та інші.

На початку проведення дослідження ми передбачали, що для успішності керівників в професійній діяльності є необхідними: високий рівень оперативної та механічної пам'яті, здатність до тривалої концентрації уваги на абстрактному (знаковому) матеріалі, вміння швидко переходити від одного виду роботи до іншого, бачити те, що знаходиться поза умовними знаками, посидючість, вміння аналізувати різні види інформації, вміння використовувати різні стратегії у розв'язанні проблеми, вміння перебудовуватися у разі необхідності, здатність працювати з різними людьми, організовувати свій час таким чином, щоб досягати поставлених заздалегідь цілей. Спільними для всіх типів професій стали також такі особистісні характеристики, які були включені до переліку для експертної оцінки, такі як вміння досягати поставленої мети, психоемоційна стійкість, здатність підтримувати психологічне здоров'я в процесі здійснення професійної діяльності. 
Таким чином, джерелом «а»-даних щодо особистісних особливостей респондентів були результати тестування. Джерелом «b»-даних поставали оцінки експертів, у яких склалися уявлення щодо поведінки респондентів в різних ситуаціях професійної діяльності.

Опишемо отримані нами результати. В групі F1 середній рівень розвитку соціального інтелекту діагностовано у 39,4\% респондентів, нижче середнього - 33,1\%, вище середнього $27,5 \%$. Серед них високий рівень ситуативної тривожності за шкалою Спілбергера-Ханіна було виявлено у $27,4 \%$ респондентів, низький - у $35,6 \%$, в той час як високу особистісну тривожність виявлено у $23,1 \%$ учасників дослідження, а низьку у $14,7 \%$. Значення показників тривожності, які пов'язані 3 професійною діяльністю (ПД), міжособистісними взаємостосунками (MB) і самооцінкою (CO) за розробленою нами методикою були такими: високі показники за ПД були виявлені у $51,6 \%$ респондентів, низькі - у 7,5\%, високі показники за МВ - у 35,6\%, а низькі - у 5,2\%. Високий рівень тривожності, пов'язаний з самооцінкою, було виявлено у 24,5\% респондентів, низький - у 15,2\%.

Отримані результати були оброблені за допомогою комп'ютерного пакету статистичних програм «Statistica»: версія 12.5.192.7, яка призначена для роботи 3 таблицями числових даних. Зіставлення результатів виявило наступне: коефіцієнт кореляції між соціальним інтелектом та ситуативною тривожністю для групи F1 склав 0,338 (на рівні значущості $\rho<0,05$ ); між соціальним інтелектом та особистою тривожністю -0,167 (коефіцієнт не значущий). Коефіцієнти кореляції між соціальним інтелектом та тривожністю, яка пов'язана 3 управлінською діяльністю, 3 міжособистісними взаємовідносинами, 3 самооцінкою $\epsilon$ такими: -0,771 (на рівні значущості $\rho<0,01$ ); -0,135 (коефіцієнт не значущий); -0,339 (на 5\% рівні значущості) відповідно.

Таким чином, наше припущення щодо наявності зв'язку між соціальним інтелектом та тривожністю керівників освітніх установ підтвердилося. При цьому значущі негативні кореляційні зв'язки були встановлені між соціальним інтелектом та ситуативною тривожністю, а також між соціальним інтелектом та тривожністю, пов'язаною 3 діяльністю і самооцінкою. Останнє ми також пов'язуємо 3 тим, що ситуація тестування викликала занепокоєння, зумовлене посереднім розвитком соціального інтелекту, тобто невмінням спрогнозувати, як саме результати тестування позначаться на професійній діяльності респондентів, як вони вплинуть на їхній соціальний статус, на їхні уявлення щодо самих себе. 3 іншого боку, з огляду на те, що такий вплив є взаємним, тривожність, а точніше їі когнітивний компонент, пов'язаний 3 негативними очікуваннями респондентів щодо своїх можливостей та оцінкою тестової ситуації як такої, могла сприяти зростанню напруги, суттєво погіршуючи отримані нами результати.

Водночас, відсутність значущих зв'язків між соціальним інтелектом та особистісною тривожністю, тривожністю, пов'язаною із взаємостосунками пояснюється тим, що тривожність як риса особистості пов'язана з наявністю глибоких психологічних проблем, характеризуючи набутий індивідом особистісно значущий досвід, а невисокий рівень розвитку соціального інтелекту сприяє некритичному сприйняттю різних ситуацій міжособистісної взаємодії. 3 цього виходить, що індивіди, які характеризуються високими показниками тривожності, більшою мірою схильні відчувати тривогу в ситуаціях міжособистісних взаємостосунків, коли вони не в змозі в силу невисокого рівню розвитку соціального інтелекту передбачати наслідки своєї поведінки та проаналізувати, як будуть розвиватися подальші події. Із усього вищевикладеного можемо зробити висновок про те, що завдяки сформованому вмінню розуміти себе та інших ми зможемо одночасно з цим знизити рівень тривожності особистості, передусім через те, що ситуацію взаємодії 3 іншими людина буде оцінювати як безпечну для себе, в результаті того, що ця ситуація буде цілковито зрозумілою для неї. 
Отже, можемо передбачити, що високий рівень соціального інтелекту та низький рівень тривожності фасилітує керівника освітнього закладу до творчості. Проте, цей висновок потребує додаткового обгрунтування на подальших етапах нашого емпіричного дослідження. Отримані нами дані респондентів за креативною мотивацією та креативною спрямованістю особистості (табл. 1) свідчать про те, що керівники освітніх установ груп F1-F3 мають досить-таки посередній рівень розвитку цих показників. Слід зазначити, що за результатами креативної спрямованості респонденти отримали більш високі показники (дані за креативною спрямованістю в професійній діяльності та у міжособистісній взаємодії).

Таблиия 1

Результати керівників педагогічних закладів освіти за показниками "креативної мотивацї̈» та «креативної спрямованості особистості» (в балах, за результатами факторного аналізу, констатувальне дослідження)

\begin{tabular}{|c|c|c|c|c|}
\hline Групи & $\begin{array}{c}\text { Креативна } \\
\text { мотивація }\end{array}$ & $\begin{array}{c}\text { Креативна } \\
\text { спрямованість }\end{array}$ & $\begin{array}{c}\text { Значення } \\
\text { t-критерію } \\
\text { Ст'юдента }\end{array}$ & $\begin{array}{c}\text { Рівень } \\
\text { значущості, } \\
\text { р }\end{array}$ \\
\hline F1 & 0,4108 & 0,6122 & 3,55 & 0,05 \\
\hline F2 & 0,4567 & 0,6572 & 4,23 & 0,01 \\
\hline F3 & 0,3219 & 0,7103 & 4,76 & 0,01 \\
\hline
\end{tabular}

Дані табл. 1 підтверджені результатами, відображеними в табл. 2. Отже, всі керівники педагогічних закладів вищої освіти мають високі результати за креативною спрямованістю особистості на спілкування та на досягнення творчих результатів у професійній діяльності. При цьому показники за креативною спрямованістю особистості на себе у всіх керівників закладів вищої освіти позначені знаком «-» та мають позитивну значущу кореляцію із креативною спрямованістю особистості на спілкування та на досягнення творчих результатів у професійній діяльності на рівні достовірності $\rho<0,01$ (для всіх груп), що свідчить щодо прагнення керівників здійснювати творчу діяльність, не фіксуватися власне на своїх здобутках, а завжди прагнути до самовдосконалення, творчого саморозвитку та творчого зростання. Розподіл керівників педагогічних закладів освіти за показником “креативна спрямованість особистості” наведено в табл. 2.

Таблиия 2

Розподіл керівників педагогічних закладів освіти за показником «креативна спрямованість особистості» (в балах, за результатами факторного аналізу, констатувальне дослідження)

\begin{tabular}{|c|c|c|c|}
\hline \multirow{2}{*}{ Групи } & \multicolumn{3}{|c|}{ Креативна спрямованість особистості } \\
\cline { 2 - 4 } & на себе & на спілкування & $\begin{array}{c}\text { на досягнення творчих } \\
\text { результатів у проф. діяльності }\end{array}$ \\
\hline F1 & $-0,3211$ & 0,6314 & 0,7009 \\
\hline F2 & $-0,2867$ & 0,6828 & 0,6913 \\
\hline F3 & $-0,2545$ & 0,6701 & 0,7214 \\
\hline
\end{tabular}

Висновки і перспективи подальших розвідок. Теоретичний аналіз проблеми професійної творчості керівника та проведене емпіричне дослідження дозволило нам сформулювати такі психологічні чинники, що визначають здатність керівника до професійної творчості: 
- професійною підготовкою керівників у вищих закладах освіти, зумовленою становленням особистісно та професійно значущого досвіду, сформованістю творчих здібностей та здатностей особистості; при цьому ці творчі здібності та здатності будуть спрямовані на досягнення ціннісних, аксіологічно значущих результатів не лише у професійній парадигмі, а й у всіх сферах життєдіяльності індивіда;

- високий рівень розвитку соціального інтелекту керівника, що передбачає здійснення особистістю творчих дій на рівні метаінтелектуальної діяльності, саме на якому і відбувається істинно творча діяльність, що призводить до експлікації творчих здобутків особистості. Саме завдяки даному, четвертому рівневі інтелекту людина здатна встановлювати взаємодію не лише із різними об'єктами та іншими людьми, а й зі світом в цілому, розширюючи тим самим межі свого інтелекту і розпочинаючи діалог із творчим початком світу;

- низький рівень тривожності особистості, що, в свою чергу, сприятиме формуванню аксіологічного творчого потенціалу особистості як фрейму, що є запобіжним фактором ціннісної дезорієнтації керівника, нівелювання ним творчих, життєздатних змін ціннісних орієнтирів, що, в свою чергу, може призвести до морального нігілізму, професійного вигорання або й до стану професійної деградації особистості.

Цими психологічними чинниками здатність керівника до професійної творчості не обмежується. В подальших наших публікаціях ми продовжимо вивчати проблему формування здатності керівника до професійної творчості, а також сформулюємо інші психологічні чинники, які зумовлюватимуть становлення творчого, аксіозорієнтованого потенціалу особистості керівника, що визначатимуть експлікацію його творчої спрямованості, творчих здобутків, творчих здібностей та здатностей тощо.

\section{СПИСОК ПОСИЛАНЬ}

Батищев, Г. С. (1998). Философия творчества. Москва.

Бердяев, Н. А. (2008). Новое религиозное сознание и общественность. Москва: ДиректМедиа. Взято с https://biblioclub.ru/index.php?page=book_red\&id=42137.

Бердяев, Н. А. (2016). Самосознание. Москва; Берлин: Директ-Медиа. Взято с https://biblioclub.ru/index.php?page=book red\&id=42279.

Бердяев, Н. А. (2019). Смысл истории. Москва: Директ-Медиа. Взято с https://biblioclub.ru/index.php?page=book red\&id=42200.

Богоявленская, Д. Б. (1983). Интеллектуальная активность как проблема творчества. Ростов-на-Дону: Изд-во РГУ.

Выготский, Л. С. (1997). Психология искусства. Анализ эстетической реакции. Москва: Лабиринт.

Гилфорд, Дж., \& О’Салливен, М. (2021). Тест «Социальный интеллект». В адаптации Елены Сергеевны Михайловой. Взято с lib.chdu.edu.ua/pdf/posibnuku/160/41.pdf.

Завгородня, О. В. (2007). Психологія художньо обдарованої особистості: гендерний аспект. Київ: Наукова думка.

Івашкевич, Е. 3. (2018). Психологія соиіального інтелекту педагога. (Дис. док. психол. наук). Інститут психології імені Г. С. Костюка НАПН України, Київ.

Лейтес, Н. С. (1992). Изучать одарённость детей. Психологический журнал, 1, 147.

Матюшкин, А. М. (1993). Загадки одарённости: Проблемы практической диагностики. Москва: Школа - Пресс.

Михальчук, Н. О., Набочук, О. Ю. \& Івашкевич, Е. Е. (2021). Методика вимірювання тривожності в професійній діяльності керівника. Рівне: РДГУ.

Парсонс, Г. Л. (1985). Человек в современном мире. Москва.

Пономарёв, Я. А. (1991). Исследование творческого потенциала человека. Психологический журнал, 12 (1), 3-11.

Рубинштейн, С. Л. (1989). Основы общей психологии (Т. 2). Москва: Педагогика. 
Тест В. Смекала и М. Кучера “Направленностьличности" Психологические и психофизиологические особенности студентов. (1977). Казань: Издательство Казанского университета.

Тест Кеттелла. 16-ти факторный личносный опросник Кеттелла. (2021). Взято с http://vsetesti.ru/357/.

Тест FPI. Фрайбургский многофакторный личностный опросник. Методика исследования личности. (2021). Взято с mnogofaktornyj-lichnostnyj-oprosnik-metodika-issledovaniya-lichnosti.

Шкала реактивної та особистісної тривожності Спілбергера-Ханіна. (2013). Взято с https://psychic.at.ua/publ/psikhodiagnostyka/diagnostika temparamentu_i_kharakteru/shkal a_reaktivnoji_situativnoji_ta_osobistisnoji_trivozhnosti_ch_d_spilbergera_ju_1_khanina/13$1-0-67$.

Amabile, T. M. (1983). The social psychology of creativity. New-York: Springer-Verlag.

Post, F. (1994). Creativity and Psychopathology: A study of 291 world-famous men. British Journal of Psychiatry, 165, 22-34.

\section{REFERENCES}

Batishchev, G. S. (1998). Filosofija tvorchestva. Moscow.

Berdyaev, N. A. (2008). Novoe religioznoe soznanie i obshhestvennost'. Moscow: Direct-Media. Vzyato z https://biblioclub.ru/index.php?page=book_red\&id=42137.

Berdyaev, N. A. (2016). Samosoznanie. Moscow, Berlin: Direct-Media. Vzyato z https://biblioclub.ru/index.php?page=book_red\&id=42279.

Berdyaev, N. A. (2019). Smysl istorii. Moscow: Direct-Media. Vzyato z https://biblioclub.ru/index.php?page=book red\&id=42200.

Bogoyavlenskaya, D. B. (1983). Intellektual'naja aktivnost' kak problema tvorchestva. Rostov-onDon: Publishing house of the Russian State University.

Vygotskyi, L. S. (1997). Psihologija iskusstva. Analiz jesteticheskoj reakcii. Moscow: Labyrinth.

Guildford, J. \& O'Sullivan, M. (2021). Test "Social'nyj intellect". V adaptacii Eleny Sergeevny Mihajlovoj. Vzyato z lib.chdu.edu.ua/pdf/posibnuku/160/41.pdf.

Zavgorodnya, O. V. (2007). Psykholohiia khudozhno obdarovanoi osobystosti: hendernyi aspekt. Kyiv: Scientific opinion.

Ivashkevych, E. Z. (2018). Psykholohiia sotsialnoho intelektu pedahoha. (Dys. dok. psykhol. nauk). G. S. Kostyuk Institute of Psychology NAPS of Ukraine, Kyiv.

Leites, N.S. (1992). Izuchat' odarjonnost' detej. Psihologicheskij zhurnal, 1.

Matyushkin, A. M. (1993). Zagadki odarjonnosti: Problemy prakticheskoj diagnostiki. Moscow: School - Press.

Mykhalchuk, N. O, Nabochuk, A.Yu. \& Ivashkevych, E. E. (2021). Metodyka vymiriuvannia tryvozhnosti v profesiinii diialnosti kerivnyka. Rivne: RDGU.

Parsons, G. L. (1985). Chelovek v sovremennom mire. Moscow.

Ponomarev, Ya. A. (1991). Issledovanie tvorcheskogo potenciala cheloveka. Psihologicheskij zhurnal, 12 (1).

Rubinstein, S. L. (1989). Osnovy obshhej psihologii (T. 2). Moscow: Pedagogy.

Test V. Smekala i M. Kuchera "Napravlennost' lichnosti" Psihologicheskie i psihofiziologicheskie osobennosti studentov. (1977). Kazan: Publishing house of Kazan University.

Test Kettella. 16-ti faktornyj lichnosnyj oprosnik Kettella. (2021). Vzyato z http://vsetesti.ru/357/.

Test FPI. Frajburgskij mnogofaktornyj lichnostnyj oprosnik. Metodika issledovanija lichnosti. (2021). Vzyato z http://psycabi.net/testy/462-test-fpi-frajburgskij-mnogofaktornyjlichnostnyj-oprosnik-metodika-issledovaniya-lichnosti.

Shkala reaktyvnoi ta osobystisnoi tryvozhnosti Spilberhera-Khanina. (2013). Vzyato z https://psychic.at.ua/publ/psikhodiagnostyka/diagnostika temparamentu_i_kharakteru/shkal a_reaktivnoji_situativnoji_ta_osobistisnoji_trivozhnosti_ch_d_spilbergera_ju_1_khanina/13$1-0-67$.

Amabile, T. M. (1983). The social psychology of creativity. New-York: Springer-Verlag. 
Post, F. (1994). Creativity and Psychopathology: A study of 291 world-famous men. British Journal of Psychiatry, 165, 22-34.

ANALYSIS OF PROBLEM OF PSYCHOLOGICAL FACTORS DETERMINING THE ABILITY OF THE MANAGER TO PROFESSIONAL CREATIVITY

Oleksandr Nabochuk

$\mathrm{PhD}$ in Psychology

Head Adviser of Rivne Regional Council, Rivne

https://orcid.org/0000-0002-1448-7687

DOI https://doi.org/10.35619/praprv.v1i16.216

\begin{abstract}
The article deals with the problem of professional creativity of the manager. It was noted that in the most theoretical definitions the essence of creativity was quite expressive, presentable and explicit in the focus of procedural, productive and personal aspects of creativity.

We described our empirical research with the aim to establish the level of the formation of creative motivation and creative orientation of the managers of pedagogical educational institutions, as well as their social intelligence and anxiety as individual characteristics, which would allow us to formulate psychological factors that determined the ability of leaders to professional creativity. A link has been established between social intelligence and the anxiety of educational leaders. Significant negative correlations were found between social intelligence and situational anxiety, as well as between social intelligence and activity-related anxiety and selfesteem. We also attribute the latter to the fact that the testing situation has caused concern due to the mediocre development of social intelligence, the inability to predict exactly how test results will affect respondents' professional performance, how they will affect their social status and their perceptions of themselves. On the other hand, given that this effect is mutual, anxiety or rather the main there are their cognitive components, associated with negative expectations of respondents about their capabilities and assessment of the test situation in such a way it could contribute to increased tension, significantly worsening our results.
\end{abstract}

Theoretical analysis of the problem of professional creativity of the leader and our empirical research allowed us to formulate such psychological factors that determine the ability of the leader to professional creativity:

- professional training of managers of higher educational institutions, due to the formation of personally and professionally significant experience, the formation of their creative abilities and possibilities of the individual; at the same time these creative abilities and possibilities will be directed on the achievement of valuable, axiologically significant results not only in a professional paradigm, but also in all spheres of vital activity of the person;

- a high level of the development of social intelligence of the manager, which involves the implementation of creative actions by the individual at the level of meta-intellectual activity, which is where the true creative activity takes place, which leads to the explication of the creative achievements of the person. Thanks to this, the fourth level of the intelligence is in that fact that a person is able to establish interactions not only with various objects and other people, but also with the world as a whole, and thus is expanding the boundaries of his/her intellect and it begins a dialogue with a creative beginning of the world;

- a low level of personal anxiety, which, in turn, will contribute to the formation of axiological creative potential of the individual as a frame, which is a precautionary factor of value disorientation of the leader, leveling his/her creative, viable changes in values, which, in turn, can lead to moral nihilism, professional burnout or to a state of professional degradation of the person.

Key words: professional creativity, creative motivation, creative orientation, social intelligence, situational anxiety, axiological creative potential of the person. 